\title{
Ce que Pennac Veut Dire: Unmasking Symbolic Violence in Daniel Pennac's Malaussène Series
}

Kirsten HALLING

$\mathrm{P}$ opular French author, Daniel Pennac is best known for his Malaussène saga', a fictional universe that both distorts and replicates the reality of contemporary French society. Chaotic and exaggerated, it comprises caricatures of individuals and groups from all walks of life who interact in a one-dimensional, comic book style. Pennac's characters interact in a microcosm of French society in which social hierarchy and cultural polarization preclude the possibility of unbiased communication. The constant tension between people from opposing socio-cultural backgrounds, and their conflicting ideologies, gives rise to complicated intrigues whose unraveling provides Pennac's tales with structure and suspense.

Pennac's talent for capturing the nuances in all forms of linguistic exchange, and subsequently undermining them by means of narrative asides or sarcastic replies, easily lends itself to a sociological reading, and in particular, a reading based on the social philosophy of Pierre Bourdieu. Bourdieu's deconstruction of social space is especially pertinent in Pennac's fiction because it provides an economically grounded analysis of the conditions of literary and oral production and reception. It examines the manner in which speakers and writers tailor their linguistic product to a certain market $^{2}$ in order to maximize profit (i.e. fame and money). 
Both Pennac and Bourdieu believe that even the most superficially innocent of linguistic exchanges entails, in varying degrees, a power struggle. The speech act is replete with unconscious, ingrained strategies for maintaining and improving one's position in society. Language, an inherited source of wealth, not a common treasure available equally to all, infers a reproduction of embedded social and political structures.

For Bourdieu, the main motivating factor in all linguistic exchanges is the struggle to accumulate capital. Capital, for Bourdieu, is not just economic or material wealth. While money certainly is one form of capital, Bourdieu delineates two other types of capital of equal importance: cultural capital, which involves one's level of education, knowledge, and learned skills; and symbolic capital, which is equivalent to prestige and honor.

Various forms of capital are passed on to children by their parents and other members of their specific habitus ("a culturally specific way not only of doing and speaking, but also of seeing, thinking and categorizing"3). A child from a wealthy background will have the triple advantage of possessing large amounts of three forms of capital: symbolic, derived from "good breeding"; cultural, a solid education; and economic, a secure financial position. This transmitted wealth provides the child with a jump-start in the race to acquire more capital, proving true the old adage that "money begets money."

Pennac's Malaussène clan defines itself by opposition to the dominant habitus. Offbeat and unconventional, they thrive in a reversed family structure, caring for their sensual mother, ignoring the identities of their fathers, and voluntarily submitting themselves to the tutelage and protection of their eldest brother. Their friends come from all social strata and include: intellectuals, drug dealers, gang members, senior citizens, immigrants, police officers, high officials, etc. The main character, Benjamin, defies all notions of class. His job experience ranges from menial labor to a position with an impressive title. Poverty is never an issue in the Malaussène household because Benjamin's resourcefulness enables the family to garner enough economic capital to stay afloat. However, their lifestyle is anything but luxurious. Notions of wealth, poverty, class, and social status slide off the Teflon-coated Malaussènes, whose concern for money and labels is minimal.

While the Malaussène clan belongs to an individual habitus, it is also recuperated by the dominant habitus precisely by virtue of its opposition. Bourdieu describes the relationship between general habitus and individual habitus as "indissociable": 
En fait, c'est une relation d'homologie, c'est à dire de diversité dans l'homogénéité ... chaque système de dispositions individuel est une variante structurale des autres où s'exprime la singularité de la position à l'intérieur de la classe et de la trajectoire. Le style "personnel" ... n'est jamais qu'un écart par rapport au style propre à une époque ou à une classe, si bien qu'il renvoie au style commun non seulement par la conformité... mais aussi par la différence.... (Bourdieu, Sens pratique 101)

The dominant habitus reflects historical divisions of power, and posits the power pyramid as intrinsic and normal. Subsets of the dominant habitus include: scholars, bankers, Protestants, Jews, Muslims, the poor, the rich, whites, minorities, etc. Although these specific subsets may have different belief systems and traditions, they belong to the dominant habitus in that they are subject to its arbitrary, but universal rules of conduct, and are controlled by an inflexible establishment that favors an inherited transferal of privilege and status.

Language is perhaps the greatest symbol of social distinction as it provides a wealth of information about one's individual habitus and predetermines one's success within the dominant habitus. Linguistic competence is elusive to those who are not born into wealth and power because such fluency requires not only perfect grammar skills and an extensive vocabulary, but also the ability to manipulate language, using symbolic violence in order to gain power: "La violence symbolique, c'est cette violence qui extorque des soumissions qui ne sont même pas perçues comme telles en s'appuyant sur des "attentes collectives," des croyances socialement inculquées" (Bourdieu, Raisons pratiques 190).

The use of symbolic violence is a pervasive theme in the works of Daniel Pennac. The Malaussènes, a family of well-educated, white orphans, raised by Arab immigrants in working-class Belleville, are forever forced into situations which reveal patterns of institutionalized injustice and lack of equality. They witness the persecution of Muslim immigrants, the subjugation of women, the mistreatment of children, the abuse of the elderly, and the self-righteousness of fundamentalist Christians. In addition, they experience first-hand the economic and cultural domination of the disempowered masses by the guardians of inherited power.

Pennac's fictional universe is a precarious world in which the strong prey upon the weak. The reader is relentlessly confronted with the corruption of public officials. Secure in their power and convinced that their high positions will camouflage their participation in shady dealings, these trusted public servants and leaders scornfully betray those whom 
they are charged to protect. Curiously, Pennac's protagonists are often able to subvert the very symbolic power that victimizes their peers despite their lowly social position. Pennac's narrator, Benjamin, penetratingly evaluates official discourse by means of sarcastic interjections and bitingly humorous narrative asides. Symbolic power leaves Benjamin unimpressed. Although Ben's child-rearing philosophy has little to do with social dictates, he raises an honest gaggle of children by emphasizing love and honesty as the principal guidelines by which to live a happy and successful life. While he teaches them about their dominant habitus by telling them literary or fabricated bedtime stories, he allows them to develop extrasocially by encouraging them to follow their hearts, not social rules.

The Malaussènes may be materially poor, but they are rich in cultural capital. Education is a priority for the children. Ben enriches the family's cultural capital by sharing folklore with them and encouraging them to develop their critical spirit; he tutors his sister Clara in anticipation of her baccalaureate exams and he tries to keep his brother Jérémy in school, and out of trouble. Ben, the misfit who never bothered to learn to drive, is surprisingly attuned to the functioning of the dominant habitus. This, in part because he is "l'honoré propriétaire" of a law degree. Thanks to his legal training, he is able to see through the machinations of the dominant habitus, but he is unwilling to use his skills for profit. Like Ben, the other members of his family are culturally well-adapted members of a society that, nevertheless, treats them as outcasts. Ben's sister Louna is a registered nurse; her husband, Laurent, is a doctor; and Ben's girlfriend, Julie is a first-class, investigative reporter.

The Malaussène's cultural wealth also derives from their special abilities. Thérèse's talent for cartomancy, palmistry, and numerology is renowned and respected, even by disbelievers; Clara's extraordinary gift for photography is a source of astonishment and admiration; and Ben's skill for shouldering blame is at once a boon and a bane. Each of these intensely different aptitudes is dependent upon a distinct form of knowledge. Thérèse's mysticism is not only based on book learning, but also on a deep inner conviction of the power of non-rational wisdom. Clara's genius for photography is born of her desire to perceive the essence behind the image; and Ben's forte for taking responsibility for the misdoings of others is a result of his immeasurable sense of humanity and his ability to empathize with all human beings.

Despite the Malaussène's cultural wealth, their relation to symbolic and economic capital is decidedly ambiguous. Their disinterest in symbolic capital is evident in their refusal to convert cultural capital into titles, 
honors, and prestige. On the edge of society, looking in, the family's acute analytical perspective allows them to see symbolic wealth as an artificial construct. Ben especially mistrusts symbolic capital. Where others boast about their accomplishments, Ben keeps his law degree secret, and refuses to put it to use. The Malaussènes function within the dominant habitus, outwardly obeying its rules and superficially compromising their beliefs in order to survive. Although Ben is loath to cash in his cultural capital for material wealth, he is willing to do so when his family verges on financial ruin. At the end of Au bonheur des ogres, when his mother returns home, "enceinte jusqu'aux dents," and bills start pouring in, Ben hurriedly accepts an employment offer he had previously refused.

Benjamin's profound understanding of the complexity of the human condition gives him the versatility of a method actor. His ability to invest himself completely in each new role is astounding. When his girlfriend and sister team up to do a special report about Ben's curious role as a professional scapegoat for a large department store, Ben returns to his job with renewed vigor, going so far as to make friends with a shallow coworker: "Quant à Lehmann, il n'en revient pas de ma toute nouvelle complicité. C'est la première fois qu'il communique, Lehmann. J'ai toutes les peines du monde à refouler ses invitations à dîner, et les autres. "Je connais une boîte, je te dis pas, une bande de suceuses comme t'en as jamais vu!" Copains, quoi" (Au bonheur 132).

Ben has the ability to judiciously adapt his level of discourse by speaking the language his receptor wants to hear. Bourdieu defines this communicative strategy as self-censorship, a discursive technique that entails anticipating the market and molding the linguistic product to suit its needs. Ben's talent for self-censorship is so pronounced that his true character is only evident to his loved ones. Interestingly, Ben is able to use deceit in a truly humanitarian context. His interaction with complaining clients and struggling writers is tinged with sympathy for these bruised human beings.

Ben's intellectual and emotional understanding of the human plight translates into bodily attitudes and postures. His talent for assuming physical positions of submission, self-abnegation, and guilt is completely dependent upon his ability to detect and relate to human suffering. For instance, in $A u$ Bonheur des ogres, an encounter with a disgruntled client, who had purchased a dangerously defective fridge, begins with a brief look into her heart: "La douleur qui perce à travers sa colère m'aide à prendre un air lamentable" (14). His tears win her over, and she benevolently refuses to let Ben bear the financial burden for the heavy 
material losses she suffered when the refrigerator she had purchased from his store became an incinerator. Later, Ben's technique for transforming anger into charity is made evident when he calmly sees through the bluster of a menacing giant: "... il est venu imposer son droit par sa force, c'est tout. Suffit de lui jeter un coup d'œ il pour comprendre qu'il n'a jamais eu d'autre mode d'emploi. Suffit de lui en jeter un second pour constater que ça ne lui a pas mené loin dans l'hiérarchie sociale. Il doit avoir un cœ ur qui le gêne quelque part" (44).

Ben is able to elicit the buried vestiges of humanity in others by radically altering his body so as to actually become the physical embodiment of guilt. When the hulk of a customer elucidates the reason for his fury (his fiancée broke a few bones when the bed he recently purchased from the department store fell apart during coïtus), Ben's body convincingly registers shock and shame:

-Oooh!

C'est un vrai cri que j'ai poussé. Un cri de douleur. Qui les a fait sursauter tous les deux.

-Oooh!

Comme si on m'avait frappé à l'estomac. Puis, compression de ma cage thoracique par la pointe de mon coude, juste au-dessous du sein, et je deviens aussi blanc que les draps du plumard fatal. Cette fois, Hercule fait un pas en avant, esquissant même le geste de me rattraper au cas où je tomberais dans les vapes.

-J'ai fait ça (44)?

In this episode, and in many more, Ben is able to penetrate his customer's individual habitus and draw out a sense of human decency. Unlike Ben's shifty co-worker Lehmann, whose physical reactions are limited to those of a classic bully (intimidation of the weak and fear of the strong), Ben is able to mold his body and language so as to appeal to the kindness of people from all levels of society. As such, he is able to transcend his bodily hexis, a term coined by Bourdieu to design a permanent, socially conditioned bodily attitude (stance, shape, dispositions).

As in the case of linguistic self-censorship, Ben anticipates his interlocutor and crafts his bodily hexis accordingly. He communicates with others, using his body, by assessing the "market" and adopting the postures and gestures that will earn him pity and indulgence. Ben's skill is unique given that one's bodily hexis is the product of one's habitus and is thus very difficult to alter. Bodily hexis is determined by physical conditions, such as: diet, exercise routine, and genetic heredity. While 
the wealthy tend to consume small quantities of fine foods like caviar, vegetable mousses, and delicate pastries, the working classes eat starchier, bulk-building foods. Further, whereas the wealthy usually work indoors, at desk jobs, working class occupations are generally more physical, requiring strength and endurance.

When Ben first glances at the huge irate customer in Lehmann's office, he is immediately able to appraise his social situation by evaluating his body type and use of space. After two quick glimpses of the massive man, he adapts his bodily hexis to that resembling a "chien battu," slinks into the room, and begins his charade. The hulking man is impressed by the sheer physicality of Ben's emotions. By instinctively adapting his bodily hexis to meet the varied expectations of persons from different social milieus, Ben proves that he cannot be pinned down to a single social class. His unusual physiological flexibility is due largely to his marginal social status and his uncanny ability to unearth the core of every human being he meets, regardless of hierarchical position.

Benjamin's judgment is, more often than not, impeccable in matters of social provenance and psychological make-up. His duties as professional scapegoat include kowtowing to heads of state, struggling writers, successful authors, mothers, businesspersons and police officers. This malleable quality can become an Achilles' heel when appropriated by the wrong people. Such is the case when Ben reluctantly agrees to impersonate J.L.B., a reclusive author of pulp fiction who seeks a standin to protect his anonymity. Forced to gain weight, wear expensive Italian suits, adopt a slick new hairstyle, Ben unhappily assumes the repulsive bodily hexis of an impossibly aristocratic commercial novelist who stands for all that he despises. Ben's pliable physiognomy becomes the passive object of another man's desire to create a stereotype. Rather than control the emergence of his new bodily hexis, Ben retreats into himself while others mold and shape him.

Ben is not the only character in the Malaussène series to change his bodily hexis at will. Inspector Pastor is able to extract confessions from the toughest of criminals by obliging his body to go through an extremely unhealthy transformation. During the course of a cross-examination, Pastor's bright, youthful demeanor slowly metamorphosizes into a "cancer" which conveys desperation, inspires fear, and incites the interrogated subject to confess as quickly as possible. Edith PonthardDelmaire, a drug-trafficker, is confused and amazed by Pastor's drastic evolution during a "chat" which begins informally, and slowly increases in intensity: 
...ce jeune inspector Pastor, avec ses joues roses, ses cheveux frisés, sa voix douce, son grand pull, avait un air de santé qui s'était altéré au fur et à mesure du récit, jusqu'à ôter toute couleur à sa peau et creuser sous ses yeux d'insondables cavernes à la mine de plomb. Edith l'avait cru tout jeune, d'abord ... mais la conversation se prolongeant, elle n'était plus du tout sûre de son âge. Sa voix aussi s'était brouillée, comme s'efface une bande magnétique, avec des enlisements soudains, et ses yeux, au fond de ses orbites, s'étaient comme figés dans un épuisement glauque. (Fée 192-3)

Pastor's "cancer," contracted during each interrogation, is a painful descent into the torrid reality of vice and corruption. Drained by his interlocutors' revelations, his tendency to suddenly "succumb" to terminal illness is a physiological representation of the evil plague ravaging humankind. As such, Pastor's bodily hexis, able to transcend social limitations, becomes a universal archetype for physical and psychological infirmity.

Unlike Benjamin Malaussène, who is unable to fathom the concept of evil, Pastor is finely attuned to the mindset of the depraved. Despite his inherited wealth and high breeding ("Les manières douces, les pullovers, le subjonctif, et l'inaptitude à l'argot que la famille avait légués au gamin" [Fée 62-3]), he is surprisingly capable of conforming his bodily hexis to different social registers as a means of obtaining respect and establishing false intimacy.

Although he despises Inspector Cercaire and suspects him of involvement in a wicked plot to murder old people, he is able to maintain a level of camaraderie with his superior that translates, for Cercaire, into moments of fatherly affection. Pastor plays Cercaire's game by showing him deference. He addresses his superior as "vous," while Cercaire uses the "tu" form when speaking to Pastor, and disrespectfully nicknames him "petit," "fils," "gamin," "mon gars." In addition, Pastor drinks beer (the social drink par excellence of the working class) with the ultra-virile Cercaire; adopts Cercaire's mode of expression: "Pastor sut rire exactement du même rire que Cercaire" (Fée 127); and uses his body to appear unthreatening: "Pastor s'était toujours bien entendu avec les malabars. Sa petite taille ne leur faisait pas d'ombre et la vivacité de son esprit les engageait à lui faire la cour" (Fée 122).

Pastor's sharp intellect and his talent for extracting truthful confessions from hardened criminals is underestimated because misinterpreted by the law enforcement body, whose methods of 
interrogation conventionally rely upon intimidation tactics. Moreover, nothing about Pastor is in keeping with the traditional image of a police officer. His small stature, good manners, shyness, and his legendary ineptitude with a gun make him an unlikely candidate for the police academy. Lacking symbolic capital within the profession, his gift for interrogation without brutality is a source of amazement for thugs like Cercaire and his cronies. Pastor is a brilliant investigator who refuses the usual trappings of his vocation. His power, paradoxically, derives from its misrecognition. Small and unassuming, Pastor's strength lies in the fact that the criminals he questions are unable to perceive him as a threat.

Recognition and misrecognition are terms coined by Bourdieu to describe peoples' reactions to social phenomena. Recognition of social power is based upon one's position in the hierarchy of legitimate authority. Benjamin, for instance, is respected as a legitimate member of the status quo because of his professional titles: Contrôle technique au Magasin, Directeur littéraire aux éditions Talion. When Inspector Cercaire retains him for questioning, he begins the conversation by addressing Benjamin as "tu." However, upon hearing Benjamin's impressive job title, he immediately switches to "vous":

-Qu'est-ce que tu fais comme boulot?

-Directeur littéraire aux Editions Talion.

-Et ça vous plaît?

(Voilà, il y a les "apparences-tu" et les "métiers-vous." Un homme simple, Cercaire. J'ai une tête de quoi avant que le titre ne vienne contredire l'apparence? Plombard? Chômeur? Marlou? Alcoolo?) (Fée 86)

But Ben's titles are merely a front for what most people would consider ignominious activities. The general misrecognition of Ben's arbitrary symbolic power as legitimate affords him a high degree of social respectability and inviolability. Cercaire's instantaneous turn-about from disdain to obsequiousness is cause for both amusement and consternation about the superficial nature of social typecasting.

Ben Malaussène, the narrator, is notorious for his skepticism and insight, as illustrated in his many narrative comments and asides, which provide an inexorable disclosure of symbolic violence disguised as authorized discourse. In La Fée Carabine, when Arnaud LeCapelier, the Secrétaire d'Etat aux Personnes Agées, delivers a congratulatory "spitche" to an exemplary senior citizen (Papy Semelle), Ben is unable to overcome his feelings of suspicion and paranoia: "Je suis la poule. Je flaire le renard" (78). Ostensibly championing the elderly, the priggish, young bureaucrat 
gives the impression of being at their service, while the innuendos in his discourse and body language are proof of his intent to dominate and exploit. LeCapelier's use of language as a strategy to gain and maintain power is painfully evident to the mistrustful Ben: "Et il a une curieuse façon de parler. Un débit "attentif," je dirais. Oui, c'est ça, il parle comme on écoute, les mots qu'il lâche, il veut les entendre pénétrer dans la cervelle de l'auditoire" (77).

LeCapelier is a disconcerting representative of the inflexible and impenetrable status quo. Born into the dominant habitus, the son of the "sous préfet," Arnaud's thirst for power is an acquired taste. As Ben correctly surmises, Arnaud does not hesitate to use all of the political and material advantages at his disposition to ruthlessly make his way to the top of the ladder: ". . .il est, depuis le berceau, programmé pour la permanence des institutions. L'Homme est un plantigrade adapté aux échelons; les pieds d'Arnaud LeCapelier doivent porter les traces de tous ceux qu'il a gravis de la Maternelle jusqu'à son poste actuel" (76). The ever-sensitive Ben is unable to detect the trace of a heart beneath LeCapellier's rigid and impeccable exterior. Because his efficient and calculated style of presentation negates the apparent solicitude of his words, Ben cannot help but interpret Arnaud's discourse as a carefully orchestrated attempt at self-censorship. LeCapellier is a man filled with hatred for the aged, and his official lecture given on behalf of old folk is filled with double-entendres to which Ben reacts with sarcasm and wit: "Il commence son spitche en se félicitant de la "belle autonomie du médaille" (sic: ça veut dire que si notre Semelle n'est plus d'âge à fabriquer des pompes, il peut encore lacer les siennes tout seul)..." (Fée 76). After a few more references to the faltering "autonomy" of the aged, coupled with high praise for state-run senior homes as a remedy for solitude and "les défaillances humaines," Ben finally realizes the reason for which such an important man would deign to speak at such a simple ceremony: "Une fois qu'on a pigé que les initiales E.P.A. désignent Etablissements pour Personnes Agées, on a compris l'essentiel de son discours, au bel Arnaud LeCapelier: de la retape pour les mouroirs, voilà ce qu'il est en train de faire" (77). As it turns out, LeCapelier's interest in the matter is even more depraved, as it involves tremendous material gain at the expense of the physical and mental well being of the elderly. Nonetheless Ben's instincts are correct, and his seemingly irrational desire to protect his ancient friends from the likes of Arnaud LeCapelier is, in fact, highly justified. 
In $A u$ bonheur des ogres, Ben is witness to another kind of symbolic dominance in the form of Professor Léonard's address to the Ligue nataliste et pour la défense de la jeunesse. This time, the representative of the social order is preaching to the choir. He speaks the same language as his right wing, reactionary listeners, and he plays upon their fear of losing power and privilege as a means of reinforcing their commitment to his cause. Again, Ben is struck by the coldness of the speaker's appearance. Silently nicknaming him "Crâne Rasé" and Crâne d'Obus," Ben is repulsed by his "large gueule totalement épilée," his "oreilles pointues," his "regard mussolinien," and his voice, "froidement métallique," which grates in Ben's ears (122).

Léonard's speech is a random, pell-mell sequence of conservative clichés. He begins his discourse by denouncing the practice of abortion as anti-Christian. He goes on to appeal to the assembly's feelings of national pride, reminding them that their votes are necessary to the realization of their common political goals. This leads him to "disserter" about the dangers of allowing immigrants into the country, specifically: "... tous les problèmes posés par ce fléau "tant du point de vue économique que sur le plan scolaire, pour ne pas parler de la sécurité en général, et de celle de nos filles en particulier. .." (123). Léonard's language and bodily hexis, perfectly suited to his conservative, bourgeois audience, invest him with legitimate authority in the eyes of his devout listeners. This is contrasted to the cynical reactions of Ben and Julie, who as outsiders, are struck by the absurdity of his propositions and the fire-and-brimstone quality of his delivery style. Like a preacher, who takes the faith of his flock for granted, Léonard's task is to keep the flock together. His speech, like Arnaud's, is manipulative, but because his audience belongs to his own habitus, and as such, shares his views, it is devoid of ambiguity. Where Arnaud LeCapelier's discourse is dangerously misleading, Léonard's is motivational and unadulterated.

Symbolic violence is also exercised in one-on-one situations, as Ben discovers when Sainclair, the director of the Department Store, requests his presence in a private meeting. Annoyed that Benjamin has broken his promise of discretion by exposing the true nature of his employment to Police Commissioner Coudrier, Sainclair advises Ben to keep his mouth shut in the future: "J'ai eu toute les peines du monde à convaincre le commissaire Coudrier que vous plaisantiez. Un conseil, Malaussène, ne jouez pas avec le feu" (122). Hearing his boss explain how he would deny the truth to the police, Ben decides to quit his job. Again, Sainclair exerts "legitimate pressure" on the squirming Benjamin by claiming that he is 
not free to leave because the police have placed a hiring and firing freeze on the store due to an ongoing bomb investigation. In a last ditch effort to regain power, Ben vows to damage the department store's image by acting like a madman in front of the customers. Sainclair reaction is to smile knowingly while warning Ben that his actions could make him the police's number one bombing suspect.

Sainclair's gift for turning conversations to his favor is not merely born of a quick wit. Handsome, charming, young, his place in the dominant habitus is well secured by virtue of his excessive assets in symbolic and economic capital. His gentle style and clever use of language earn him the undying adulation of his employees whom he prefers to call his "collaborators." Sainclair's confidence is unshakable: "Il a l'autorité douce. Il sort d'une boite supérieure de commerce où on lui a d'abord appris à poser sa voix et à s'habiller. Le reste est venu tout seul. Il parle presque tendrement, et sous sa blonde mèche filtre un doux regard cerné de tristesse. ... Pas de doute, il a un don, Sainclair. Il a compris un truc que je ne comprendrai jamais" (38-39).

Not only is Benjamin wary of the arbitrary nature of symbolic power invested in legitimate authority figures, he is also skeptical of all belief systems since he considers them responsible for the perpetuation of social stratification. He perceives organized religion as an elaborate and artificial structure for preserving the caste system through the propagation of the persuasive metaphysical notions of Heaven, Hell, and Purgatory. Ben's attack on philosophical systems also extends to literary criticism, and is no less categorical. In La petite marchande de prose, novels by the mysterious J.L.B. are invariably centered around the "rags to riches" thematic. The characters are said to be drawn from real-life models, however their fantastically rapid rise to instant success and happiness places this genre in the realm of the fairy tale. For instance, in Le seigneur des monnaies, the protagonist, Philippe Ahoueltène, goes from garbage man to tycoon in the blink of an eye. After securing his fortune, he learns to speak five languages fluently, becomes a professor, learns to play the saxophone, and is drafted as a professional rugby player - all in the space of two years. Unfortunately, such an ability to effortlessly acquire first economic, then cultural and symbolic capital is possible only in a fantasy land where every member of society begins the game with an equal amount of capital and a fair shot at reaching the top rung of the social ladder.

Despite the fact that J.L.B.'s philosophy of success "Vouloir, c'est vouloir ce qu'on veut" is appealing to the working class, his logic is 
misguided. Deprived of cultural capital (good schooling, an ingrained understanding of social rules, linguistic capital), a garbage man's probability of acquiring status and wealth is negligible. In the rare cases when a member of the working class manages to gain economic power without first acquiring cultural capital, his/her place in the dominant habitus is far from assured. Cultural capital is not acquired overnight, as J.L.B. would have his reader believe. It is inculcated from birth, and is a telltale and inescapable sign of one's habitus. Moreover, by implying that any member of society can accede to power, J.L.B.'s novels strengthen the hold of the upper classes over the lower. The mere possibility of achieving wealth and prestige within the system prevents the people from revolting against the system.

J.L.B. provides his readership with false hope by suggesting that money and power are easily obtainable with enough willpower and creative commercial thinking. However, he also cleverly negates this message by building an impenetrable wall around the habitus of the wealthy, implying that only a truly exceptional individual could break into the power structure. Philippe Ahoueltène, the garbage collector-turned billionaire, is a superhero figure who, in no way resembles the common shopkeeper or businessperson. His personal trajectory is a cliché-ridden dream shared by the downtrodden. His ability to penetrate the most elite social circles, earning immediate respect and recognition, is possible only in an ideal world and through superhuman feats.

The only superhuman feat Pennac's characters perform is that of staying alive in a world ruled by the elite inheritors of power and privilege. Benjamin's wry acknowledgment of discursive power strategies implicates the reader in the game and heightens the reader's awareness of the economic nature of linguistic exchange. Pennac's dismantling of the dominant habitus is achieved indirectly, by means of humor, hyperbole, and the constant subversion of socio-cultural clichés.

Wright State University

\section{Notes}

1. To date, Daniel Pennac's Malaussène saga comprises five novels, Au bonheur des ogres (1985), La Fée Carabine (1987), La petite marchande de prose (1989), Monsieur Malaussène (1995) and Aux fruits de la passion (1999). 
2. Terms coined by Bourdieu are italicized throughout the text.

3. http://www.hyperdictionary.com/dictionary/habitus

\section{Works Cited}

Bourdieu, Pierre. Ce que parler veut dire: l'économie des échanges linguistiques. Paris: Fayard, 1982.

-. Le Sens pratique. Paris: Minuit, 1980.

—. Les Règles de l'art: genèse et structure du champ littéraire. Paris: Seuil, 1992.

- Raisons pratiques: sur la théorie de l'action. Paris: Seuil, 1994.

Lane, Jeremy F. Pierre Bourdieu: A Critical Introduction. London: Pluto Press, 2000.

Pennac, Daniel. Au bonheur des ogres. Paris: Gallimard, 1985.

- La Fée Carabine. Paris: Gallimard, 1987.

- La petite marchande de prose. Paris: Gallimard, 1989. 